\title{
Exploring the Role of Islamic Work Ethics for Organizations in Indonesia
}

\author{
Syaiful Bakhri ${ }^{1}$, Rudi Prasetyo Ardi $^{2}$, Fuad Mas'ud ${ }^{3}$, Suharnomo $^{4}$ \\ Faculty of Economics and Business, Universitas Diponegoro, Indonesia \\ syaifulpoles@gmail.com
}

\begin{abstract}
Management as a science used in organizational operations, especially in the human resources management. Through management, the goals of the organization are planned, organized, actuated and controlled so the results are expected to meet expectations. In practice, humans as the subject as well as the object of human resources turned out to do a lot of negative behavior that affect the work. Ethics is an important thing in society including for the organization because it contains values that will encourage a person to work optimally and always accompanied by an umbrella of conscience. The result of the study is a conceptual framework to provide an understanding of the use of Islamic work ethics for organizations in Indonesia which the population majority are Moslems. Islamic Work Ethics is the answer that can be used to guide the positive behavior of workers. Furthermore, Conceptual framework, theoretical and practical implications which proposed in the present study will be used as future references for those who are interesting in the work ethics, human resource and its relationship related existing variables.
\end{abstract}

Keywords - islamic work ethic, human resources, organization

\section{INTRODUCTION}

Ethics is an important thing in society including for the organization because it contains values that will encourage a person to work optimally and always accompanied by an umbrella of conscience. Ethics generally denotes a standard of morality in a society where each individual learns to distinguish what is right and what is wrong [1]. According to [2] work ethic is important because employee behavior greatly contributes to the success of an organization in the global market. Work ethics has a good impact on individual behavior in work because it can provide a stimulus for a positive work attitude.

Indonesia is a predominantly Muslim country. As a country with the population majority is Islam, of course, the majority of existing labor adheres to the same religion. This condition causes the principles of Islamic teachings are widely adopted in the context of work place, including work ethics in Indonesia.

Islamic Work Ethics refers to the moral standards of work carried out by a Muslim employee so as to produce a positive performance against the organization or company. Islamic work ethics encourages the emergence of cooperation, guidance, equality, unity and spirituality in the workplace [3]. Furthermore, according to Danhauser in [3] stated that the practice of Islamic Work Ethics in the workplace will create creativity, honesty and trust.

Discourse on work ethics based on beliefs is important given the emergence of negative behaviors when carrying out professional work. Behaviors such as non-discipline, dishonesty, injustice, administrative accountability, neglect, and other negative behaviors provide evidence that behavioral issues arising from members of the organization will cause major problems if not resolved soon [4].

One of the most obvious evidence is when one of the big companies in America, Enron corporation, bankrupt. It turns out Enron bankruptcy is derived from the occurrence of moral hazard behavior including the manipulation of financial statements to record a profit of 600 million US dollars when the company suffered losses. The manipulation of profits is due to the desire of the company to keep investors interested. An American Senator, Levin, eloquently commented on the incident "What is happening in Enron is not a failure of rules and laws, it is a failure of corporate culture, failure of values, heart failure" [5].

The above events serve as an indisputable example that not enough organizations or companies have human resource assets but more importantly have ethical human resources. Therefore, the management of ethical human resources requires treatment that is not easy to even be considered carefully. A complex problem often encountered by leaders in organizations or companies is how to keep members' behaviors in line with expectations. 
Therefore there is one big question related to the problems that arise. What are the worker's standard characteristics of work behavior that are capable of eliminating or at least minimizing the negative behaviors mentioned earlier? This paper attempts to offer an Islamic Work Ethics utilization solution that can be used in order to manage human resource issues so that it can be used in order to guide the positive behavior of workers especially in Indonesia.

Discussion about ethics has become an issue of interest in recent years. This issue is in the spotlight due to the emergence of heated debates among the experts [6]-[9]. According to [10] several factors that become controversy are: 1) The existence of various opinions related to the philosophical basis of ethics. 2) Absence of standard to determine what is meant by ethical action. 3) Violations of ethics in the business world still happens a lot.

Although still a controversy, the issue of ethics still received widespread attention from researchers. Books, journals and articles keep popping up. Even one of the clusters of ethics that is business ethics to be his own courses in several colleges of economics and business. This indicates that the discussion of ethics is always interesting to study.

Study on ethics is an interesting study for researchers. Reference [11], stated that work ethics has a relationship with job satisfaction, reference [1] states that work ethics is related to employee performance, and [12] stated that work ethics influences employment decisions. Several other studies linked work to religious values. Reference [13]-[20] examined the protestant work ethics (PWE). There are also studies linking work ethic with Confucian culture [21]-[24].

The study of work ethics associated with religious values has long been in demand by western and eastern researchers. In various studies of religious anthropology conducted, can be found a positive correlation between religious values with work ethics. Reference [25] found that the Protestant work ethic has produced the concepts of simplicity, individualism, discipline and hard work. Similarly, the Confucius work ethic proved able to encourage economic growth of the South Korean nation, dubbed the economic miracle [24].

So what about the Islamic work ethic? Basically, Islam's view of work ethic has in common with other religious teachings. However, Islam has a principle of typical work ethics that distinguishes it from other teachings. Islamic work ethics emphasizes more intentions than merely results Yousef in [25].

Thus, from the literature obtained, it is assured that the talk of work ethics will always be related to the values of religiosity possessed by a person. This becomes relevant, given how a person's view of what he is doing is strongly influenced by his basic beliefs.

The definition of Islamic work ethics itself can be understood from Beekun's explanation in [26] which stated that the Islamic work ethic is a collection of work related to moral principles and values that distinguish between right and wrong in the Islamic context. This definition provides an explanation that Islamic work ethic values encompass all dimensions of life including work within an organization [3].

Islamic work ethics is an orientation that shapes and influences the involvement and participation of followers in the workplace. Islamic work ethics is built on four basic concepts, namely business, competition, transparency and moral responsibility. Enterprises are considered as the basic ingredients in serving oneself and others. Every individual must compete fairly and honestly and work with good intentions. Trade and transactions must occur in an environment of mutual openness and trust, therefore, transparency determines moral responsibility. Moral behavior is an essential prerequisite for maintaining economic prosperity and the business community [27].

Although there are differences in basic principles, especially on the basis of reference or source, normatively, the Islamic Work Ethic is not much different from the Protestant Work Ethic. Some values such as hard work, responsibility, honesty, justice, loyalty to superiors are also found in the Islamic Work Ethic. Reference [28] points out other values of Islamic Work Ethics such as positively oriented towards work and balancing between individual and social life.

The first identification of Islamic Work Ethics put forward by [29]. Furthermore, research on Islamic Work Ethics was developed by [30]. From the results of development through factor analysis 
based on the scale made by Ali on the Islamic Work Ethics, Saad identified that the Islamic Work Ethic has three main dimensions, namely Personal and Organizational Obligations, Personal Investment and Dividends and Personal Effort and Achievement.

Furthermore Saad explains what is meant by the dimension of Islamic Work Ethics Individual and Organizational Obligations is a mental attitude or a Muslim's way of looking at, perceiving, appreciating and appreciating a work's value is an obligation, Individuals or as members of the organization.

This dimension is closely related to the level of a Muslim's belief in the truth of his Islamic teachings which states that the work he does is always interpreted as a form of worship. A Muslim who believes that the work he does is an obligation, the implications of the attitude that arises are to have a dedication to his work, happy to cooperate with others and so forth.

Furthermore, the dimensions of Personal Investment and Dividends are a mental attitude or a Muslim's way of looking at, perceiving, appreciating and appreciating a value of work that is done is an investment and therefore will bring $\mathrm{A}$ valuable outcome for himself. Some attitudes that represent this dimension for example, work means self-respect, work gives an opportunity for someone to become independent and so on.

Then the last dimension of Islamic Work Ethics is personal effort and achievements. This dimension has a sense as a mental attitude or a way of a Muslim in looking at, perceive, appreciate and appreciate a value of work done is a series of efforts that must be realized for the expected goal can be achieved.

This dimension believes that the work done by a Muslim is a logical consequence that must be borne as a concrete manifestation of the desire to achieve the expected goal. A Muslim who has this belief will always try to adjust the expected goals with the efforts he undertakes. Some attitudes that represent these dimensions include working hard, working according to the time set, confident and so forth.

Islamic work ethics sees the goal of working not as a mere completion of work, but to encourage personal growth and social relations [31]. This is important because it not only benefits the individual who holds the principle, but the Islamic Work Ethics also has an impact on the environment as a whole.

Reference [32] developed a multidimensional model of Islamic work ethics in order to make it more different from other work ethics. This multidimensional model is different from that developed by [28] which only divides the ethical dimensions of Islamic work based on three dimensions. From the results of the research, there are seven dimensions of Islamic work ethics: justice and fairness, work results for the Islamic ummah, cooperation and collaboration, trusteeship, work intention, work type, work as the source of ownership.

Reference [33] explains about Islamic Work Ethics dimensions as follow: 1. work Intention is the intention in doing a job; 2 . trusteeship is trust which should be a part for Muslims to have a large social capital in socio-economic relations; 3 . work

type is choosing the right work in accordance with the capacity and not to contradict the Islamic Shari'a; 4. work results for Islamic Ummah results means working should be profitable, providing strength and potential for Muslims without harming other people; 5 . justice and fairness means truth and justice in Islamic economics must provide welfare for all people; 6 . cooperation and collaboration means helping each other and working together in the work will help improve teamwork and can support increased productivity in the company; and 7. work as the only source of ownership means that working is the only way to gain welfare if done in earnest and full of motivation.

The following Table I contains about Islamic Work Ethics dimensions and expected performance.

TABLE I

DIMENSIONS OF ISLAMIC WORK ETHICS AND EXPECTED PERFORMANCE

\begin{tabular}{|l|l|l|}
\hline No & Dimensions & Expected performance \\
\hline 1 & Cooperation \& Collaboration & Teamwork \\
\hline 2 & $\begin{array}{l}\text { Work result for Islamic } \\
\text { Ummah }\end{array}$ & Productivity \\
\hline 3 & Justice and fairness & Knowledge sharing \\
\hline 4 & Work type & Competence \\
\hline 5 & $\begin{array}{l}\text { Work as the only source of } \\
\text { ownership }\end{array}$ & Hard work \\
\hline 6 & Work Intention & Loyalty \\
\hline 7 & Trusteeship & Responsibility \\
\hline
\end{tabular}


From Table I above we can conclude that the seven dimension of Islamic Work Ethic is a guidance to order emplyoees in workplace, so the performance may fit with organizations expected.

The diverse dimensions of this work ethic of Islam provide evidence that Islamic teachings are very comprehensive that regulates all issues including in terms of work and work. Various dimensions of work along with its explanation also gives meaning to us that the Islamic Work Ethics can be a solution to the emergence of biases of human resource behavior. That is, socialization of Islamic work ethics can be utilized as part of the achievement of organizational goals.

Organization in the world is faced with the swift choice of use of management models derived from Europe [34] or America [35] which is not necessarily match the characteristics in certain countries including in Indonesia. Different cultural characteristics, ways of thinking, geographical background and world view have led to European or American model management unsuitable or even inappropriate to apply in the context of organizational management in Indonesia, including ethics.

Given how important ethics affect the way a person works, it is no wonder the Islamic work ethic becomes an interesting part to be studied. The study of the influence of work ethics based on religious values (Islam) has been widely practiced and found some positive behaviors such as innovative working behavior [36], organizational justice [37], innovation ability [38], organizational citizenship behavior and knowledge-sharing behavior [25].

Another positive result of what is expected of the Islamic work ethic is the emergence of organizational commitment from employees or members of the organization. Allen and Meyer in reference [39] argue that organizational commitment is a psychological expression that defines the relationship between an employee and his organization and the decision to continue or discontinue membership in the organization. In another sense the concept of commitment is a consistent behavior.

Commitment becomes important because the concerns, goals and needs of employees must have relevance to the organization of the best employees [40]. This means that if the organization is able to produce the best employees then directly the sustainability of the organization will be more lasting. Employees will be loyal to work and have no desire to move to another organization, so in turn the organization will have employees who have enthusiasm in achieving the expected goals. In other words, the organization benefits from a committed workforce because it tends to be minimal in absence and contributes positively to organization [41]. Supporting research conducted by [41], the value of spirituality in the workplace has a positive effect on organizational commitment [42].

\section{CONCLUSIONS}

A complex problem often encountered by leaders in organizations or companies is how to keep members' behaviors in line with organization expectations. The key word is meticulous. It is the carefulness in managing human resources that will bring the organization to its goal. This precision also includes how the organization's leadership uses the background of beliefs to encourage positive behavior of the workers so that organizational goals can be achieved.

Understanding of the role of Islamic work ethics is actually part of the way to find ways to how the operationalization of organizations especially in Indonesia runs optimally. In the waning of religionbased worldviews in the practice of organizational life, Islamic work ethics is worthy of use as a guideline for organizations in regulating the behavior of their human resources.

\section{REFERENCES}

[1] Mathani, B A. (2016). The Significance Of Work Ethics n Human Resource Management For Upgrading The Performance Of Employees: An Applied Study. European Scientific Journal, 12 (4):231-258.

[2] Komari, N. \& F. Djafar. (2013). Work Ethics, Work Satisfaction and Organizational Commitment at the Sharia Bank, Indonesia. International Business Research, 6 (12):107-117.

[3] Ahmad, M S. (2011). Work ethics: An Islamic prospective. International Journal of Human Sciences, 8 (1):850-859.

[4] Mangkuprawira, T S. (2010). Pentingnya Etika Dalam Lingkungan Kerj. [cited 10 November 2016].

[5] Pomeranz, F. (2004). Ethics: toward globalization. Managerial Auditing Journal, 19 (1):8 - 14.

[6] Duska, R. (2000). Business Ethics: Oxymoron or Good Business? Business Ethics Quarterly, 10 (1):111-129.

[7] Lozano, J M. (1996). Ethics and Management: A Controversial Issue Journal of Business Ethics, 15:227-236. 
[8] Carlin, W B. \& K, C Strong. (1995). A Critique of Western Philosophical Ethics: Multidisciplinary Alternatives for Framing Ethical Dilemmas. Journal of Business Ethics, 14:387-396.

[9] Hoffman, W. M., and J. M. Moore. (1982). What is Business Ethics? A Reply to Peter Drucker. Journat of Business Ethics, 1:293-300.

[10] Mas'ud, Fuad. (2015). Menggugat Manajemen Barat: Mengungkap Pandangan Dunia yang Tersembunyi yang Menjadi Dasar Konsep, Teori dan Praktek Manajemen Barat. Semarang: Badan Penerbit Universitas Diponegoro.

[11] Vitell, S. J., and D. L. Davis. (1990). The Relationship Between Ethics and Job satisfaction. Journal of Business Ethics, 9:489-494.

[12] Judge, T. A., and J. Robert D. Bretz. 1992. Effects of Work Values on Job Choice Decisions. Journal of Applied Psychology, 77 (3):261-271.

[13] Furnham, Adrian and Muhiudeen, Clare. (1984). The Protestant Work Ethic in Britain and Malaysia. The Journal of Social Psychology, 122 (2): 157-161

[14] Schaltegger, Christoph A \& Torgler, Benno. (2010). Work ethic Protestantism, and human capital. Economics Letters, 107 (2): 99-101.

[15] Linz, Susan J and Chu, Yu-Wei Luke. (2013). Weber, Marx, and work values: Evidence from transition economies. Economic Systems, 37 (3): 431-448.

[16] Hassall, Stacey L. et al. (2005). Comparing the Protestant work ethic in the employed and unemployed in Australia. Journal of Economic Psychology, 26 (3): 327-341.

[17] Tang, Thomas Li-Ping. (1993). A Factor Analytic Study of the Protestant Work Ethic. The Journal of Social Psycholog, 133 (1): 109111.

[18] Furnham, Adrian \& Rajamanickam, R. (1992). The Protestant Work Ethic and Just World Beliefs in Great Britain and India. International Journal of Psychology, 27 (6): 401-416.

[19] Furnham, Adrian et al. (1993). A Comparison of Protestant Work Ethic Beliefs in Thirteen Nations. The Journal of Social Psychology, 133 (2): 185-197.

[20] Beit-Hallahmi, Benjamin. (2010). Personal and Social Components of the Protestant Ethic. The Journal of Social Psychology, 109 (2): 263267.

[21] Wang, J., G. G. Wang, W. E. A. Ruona, \& J. W. Rojewski. (2005). Confucian values and the implications for international HRD. Human Resource Development International, 8 (3):311-326.

[22] Zhang, Y. B., M.-C. Lin, A. Nonaka, \& K. Beom. (2005). Harmony, Hierarchy and Conservatism: A Cross-Cultural Comparison of Confucian Values in China, Korea, Japan, and Taiwan. Communication Research Reports, 22 (2):107-115.

[23] Yum, J. O. (1988). The impact of Confucianism on interpersonal relationships and communication patterns in East Asia. Communication Monographs, 55 (4):374-388.

[24] Kim, A. E., \& G.-s. Park. (2003). Nationalism, Confucianism, work ethic and industrialization in South Korea. Journal of Contemporary Asia, 33 (1):37-49.

[25] Murtaza, G., et al. (2014). Impact of Islamic Work Ethics on Organizational Citizenship Behaviors and Knowledge-Sharing Behaviors. Journal of Business Ethics, 133 (2):325-333.

[26] Rokhman, Wahibur and Hassan, Arif. (2012). The Effect of Islamic Work Ethic on Organisational Justice. African Journal of Business Ethics, 6 (1): 25-29.

[27] Ali, A. J. \& A. Al - Owaihan. (2008). Islamic work ethic: a critical review. Cross Cultural Management: An International Journal, 15 (1):5-19.

[28] Saad, I. A. (1998). Individualism \& Islamic Work Beliefs. Journal of Cross-Cultural Psychology, 29 (2):377-383.

[29] Abbas Ali. (1988). Scaling an Islamic Work Ethic. The Journal of Social Psychology. 128 (5): 575-583.

[30] Darwish A. Yousef. (2000). Organizational commitment as a mediator of the relationship between Islamic work ethic and attitudes toward organizational change. Human Relation.,53 (4): 513-537.

[31] Hayati, K., \& I. Caniago. (2012). Islamic Work Ethic: The Role of Intrinsic Motivation, Job Satisfaction, Organizational Commitment and Job Performance. Procedia - Social and Behavioral Sciences 65:272277.

[32] Chanzanagh, Hamid Ebadollahi \& Akbarnejad, Mahdi. (2011). The meaning and dimensions of Islamic work ethic initial validation of a multidimensional IWE in Iranian society. Procedia - Social and Behavioral Sciences. 30: 916 - 924.

[33] Nurmatias, F. (2015). Pengaruh Etika Kerja Islam, Komitmen Organisasi terhadap Kinerja Karyawan di Institut Agama Islam Tafaqquh Fiddin Dumai. Jurnal Tamaddun Ummah, 1 (1):1-14.

[34] Wallerstein, I. (1997). Eurocentrims and Its Avatars: The Dilemmas of Social Science. Sociological Bulletin 46 (1):21-39.

[35] Mas'ud, F. (2004). Mitos Keuniversalan Teori Manajemen Amerika. Jurnal Studi Manajemen \& Organisasi, 1 (1):10-21.

[36] Javed, B., S. Bashir, M. Y. A. Rawwas. \& S. Arjoon. (2016). Islamic Work Ethic, innovative work behaviour, and adaptive performance: the mediating mechanism and an interacting effect. Current Issues in Tourism: $1-17$.

[37] Khan, K., M. Abbas, A. Gul. \& U. Raja. (2013). Organizational Justice and Job Outcomes: Moderating Role of Islamic Work Ethic. Journal of Business Ethics, 126 (2):235-246.

[38] Kumar, N. \& R. C. Rose. (2012). The impact of knowledge sharing and Islamic work ethic on innovation capability. Cross Cultural Management, 19 (2):142-165.

[39] Ayazlar, G. \& B. Güzel. (2014). The Effect of Loneliness in the Workplace on Organizational Commitment. Procedia - Social and Behavioral Sciences, 131:319-325.

[40] Devece, C., D. Palacios-Marqués, \& M. Pilar Alguacil. (2016) Organizational commitment and its effects on organizational citizenship behavior in a high-unemployment environment. Journal of Business Research, 69 (5):1857-1861.

[41] Anvari, R., N. N. A. Mansor, S. A. B. P. A. Rahman, R. H. B. A Rahman. \& S. H. Chermahini. (2014). Mediating Effects of Affective Organizational Commitment and Psychological Contract in the Relationship between Strategic Compensation Practices and Knowledge Sharing. Procedia - Social and Behavioral Sciences 129:111-118.

[42] Fanggidae, Rolland. et al. (2016). Effect of a Spirituality Workplace on Organizational Commitment and Job Satisfaction (Study on the Lecturer of Private Universities in the Kupang City-Indonesia). Procedia - Social and Behavioral Sciences, 219: 639-646. 